\title{
Managing Land and Water under Changing Climatic Conditions in India: A Critical Perspective
}

\author{
Sushanta Mahapatra ${ }^{1}$, Sudip Mitra ${ }^{2 *}$ \\ ${ }^{1}$ School of Business-Economics, Amrita Institute of Medical Science Campus, Amrita University, Kochi, India; ${ }^{2}$ School of Environ- \\ mental Sciences, Jawaharlal Nehru University, New Delhi, India. \\ Email: sushanta.mahapatra@gmail.com, *sudipmitra@yahoo.com
}

Received June $18^{\text {th }}$, 2012; revised July 28 ${ }^{\text {th }}, 2012$; accepted August $29^{\text {th }}, 2012$

\begin{abstract}
In the case of developing economies, climate change and its economic consequences presume vital importance in the process of realizing sustainable development in the longer timeframe. Land and water are the two major ingredients of the successful realization of this process. It is needless to say that land and water cannot be disconnected while addressing the issue of sustainable development. Here, this paper would concentrate on the issue of water where many issues would be equally relevant to the issues of land. It has been concluded in the Natural Resources Defense Council report that, the global warming may increase the risk of floods, so an efficient and conservative water use will be of paramount importance for future water supply. The main motivation of this paper is to discuss the water management challenges that can handle the threats or stresses like Global Environmental Change (GEC), climate changes, natural disasters like flood, drought or even an extreme climatic event like cyclone. The current paper focuses on the broad area of water management issues such as the major river system of India, condition of ground water resources, the current water utilization, water losses, water under stress, water pollution and increased population \& its impact on the problem of scarcity of water. It also focuses on the water policy, land and water rights and act, Interstate Water Dispute Act etc. An attempt has been made to illustrate the environmental interface between land, water and climate. The paper assumed an interdisciplinary approach combining knowledge from environmental sciences with social sciences.
\end{abstract}

Keywords: Agriculture; Climate Change; Global Warming; Land; Water Management; Sustainable Development; India

\section{Introduction}

The problem of land and water scarcity and its management with respect to changing climatic conditions has been attracting the critical attention of various disciplines such as: engineers, Non Governmental Organisations (NGO's), activists, policy makers, researchers and academicians in the subject of land and water resources, hydrology, environmental studies, geological studies and development studies. The system of rain-fed farming is the major source of livelihood. Both land and water is the principal component of natural resource and is an indispensable requirement of the living being. Due to lack of appropriate irrigation amenities in many places, the achievement of the crop depends closely on the arrival of monsoon at the right time and in ample magnitude. Various attempts have been made to develop the water management practices in rural India. But many efforts have often unsuccessful to think about the governance and property rights issues in land and water market. It has been concluded in the Natural Resources Defense

${ }^{*}$ Corresponding author.
Council (NRDC) report that, the global warming may increase the risk of floods, so an efficient and conservative water use will be of most important for future water supply [1]. A recent World Bank report on climate change impacts in drought and flood affected areas: case studies from India articulated that India can add its climate resilience from end to end through a mixture of measures and right incentives designed at multiple levels of government. This report argued that, in the arid study regions of Andhra Pradesh, climate projections signify considerably higher temperatures i.e. $2.3^{\circ} \mathrm{C}-3.4^{\circ} \mathrm{C}$, on average and a modest rise but more irregular rainfall of about 4 percent to 8 percent at the basin level [2]. The current paper focuses on the broad area of water management issues such as the major river system of India, condition of ground water resources, the current water utilization, water losses, water under stress, water pollution and increased population \& its impact on the problem of scarcity of water. It also focuses on the current water policy, land and water rights act, Interstate Water Dispute Act etc. An attempt has been made to illustrate the environmental interface between land, water and climate. 


\section{Global Environmental Change and Sustainable Development: Issues and Concerns}

Climate change in the framework of sustainable development has a number of connotations. Such an approach means that poverty eradication and socio-economic development are necessary for combating climate change. The outcomes of the World Summit on Sustainable Development (WSSD) make stronger the model of sustainable development by addressing its three dimensions: economic, social, and environmental. The international community has acknowledged the relationship between climate change and development, as reflected in the outcome of the 8th Conference of the Parties (COP) to the UNFCCC (United Nations Framework Convention on Climate Change ) in New Delhi, 2002, as well as the plan of implementation adopted at the WSSD in 2002 [3]. The eleventh conference of the parties to the UNFCCC in December 2005 initiated a discussion to analyse the policy approaches for long term cooperative action to deal with climate change, focusing on sustainable development, adaptation, technology, and market-based opportunities. The Johannesburg Plan of Implementation (JPOI) of WSSD, 2006 focused on climate change and its adverse effects and clearly links it with poverty and other development concerns, such as land degradation, access to water and food, and human health. Poverty eradication and socio-economic development are necessary for fighting climate change. The United Nations system is moving toward an integrated approach to dealing with climate change by enhancing inter-agency co-operation, in this process highlighting the centrality of the convention, supporting the market-based mechanisms and the role of the private sector, and welcoming complementary initiatives [4].

Executing sustainable development goals can lead to a development trajectory that combines economic growth with climate change mitigation. The efforts to fight climate change will have to be integrated into the broader concept of social and economic development. Tackling the global warming problem due to climate change and its economic consequences assume vital importance in the process of achieving sustainable development, particularly in the developing economies. Sustainable development means meeting the needs of the present without compromising the ability of future generations to meet their own needs [5]. The main principle of sustainable development is the integration of economic, social and environmental concerns in policy making. There is broad agreement that international cooperation on the twin aspects of mitigation and adaptation should be promoted. Adaptation is acknowledged as an essential for all countries, but mostly for those vulnerable due to their geographic location or level of socio-economic development, such as Small Island developing States (SIDS) and least developed countries (LDCs) [3].

\section{India's Water Resources Potential}

India is having four per cent of the world's fresh water resources, and 16 per cent of the world's population. The per capita availability of freshwater has fallen from over 5000 cubic meters per year in 1947 to 2000 cubic meters per year in 1997. Total water potential available of India is 1132 Billion cubic meter and total exploitable irrigation water potential is 384 Billion cubic meter. Various factors affecting availability of water are urbanization and population growth, rainfall pattern, uneven distribution of water, pollution of surface water etc. The paucity of precipitation in several crop seasons has resulted in crop crash and drought situation in huge parts of the country. The whole accessible water enduring approximately same and population increasing exponentially creates a monumental burden on the water resources. It necessitates the obligation for evaluating the water resources and planning its consumption. There is highly seasonal pattern of rainfall, with 50 per cent of precipitation falling in just 15 days and over 90 per cent of river flows occurring in just four months [6].

The Indian mainland is drained by 15 major, 45 medium and over 120 minor rivers, besides numerous ephemeral streams in the western arid region. The different types of river comprised in terms of areas such as for Major river (drainage basin area $>20,000 \mathrm{~km}^{2}$ ), medium river (2000 to $\left.20,000 \mathrm{~km}^{2}\right)$ and minor rivers $\left(<2000 \mathrm{~km}^{2}\right)$ rivers. The country's total water resource is divided into 19 major drainage regions [6,7]. In the present context, the mostly debatable concept is the feasibility, desirability and viability of the idea of interlinking of rivers. Can the idea of river linking solve India's water problem? Many authors has critically examined the grand vision of linking of rivers and found it added of an illusion [8-11]. Based on the presupposition data, Vaidyanathan study reveals us that, there are large surplus flows in some basins and that the physical transfer is viable in terms of physical engineering and can be realized economically devoid of generating any undesirable impact. His analysis imposes certain important questions such as on what basis, who resolves the surplus basins and the magnitude of the surplus? His study clarifies that most of the basins may have floods in the monsoon but have insufficient water for use in the dry season. Furthermore, since the surplus take place in the rainy season and the requirement is in the dry season, it is not sufficient to simply carry the water from one point to another. He described that one needs to identify the quantum of water to be stored, and whether and where potential spot in the re- 
quired scale are available, and their possible effect on environment and human displacement [8-10].

Around 10 and 35 per cent of the entire country is covered by the Indus and Ganga-Brahamputra-Meghna systems respectively, which are depicted by widespread flood plains and deltas. India is experiencing the key extreme climatic events such as floods, droughts and cyclones. About $40 \mathrm{~m}$ ha (12.16 per cent of total land area) is under flood prone area in India [12]. Many parts of the country have been declared as drought prone. For example Western parts of Rajasthan and the Kutchh region of Gujarat are chronically drought affected. Drought conditions have also been reported by many studies in Karnataka, Andhra Pradesh, Orissa and Bihar states [13]. Drought disasters are more frequent during years following El Nino/Southern Oscillation (ENSO) events. At least half of the severe failures of the Indian monsoon since 1871 have occurred during EI Nino years [6,14]. All the rivers play a key role in the economy of India through sustaining agriculture, industry, and energy generation and by providing ecological services. One can come across spatial variation in mean annual precipitation that ranges from about $100 \mathrm{~mm}$ in western Rajasthan to more than $2500 \mathrm{~mm}$ in northeastern areas and again a world maximum of 11,000 mm near Cherrapunji. In his extensive study Bandyopadhaya described that this is attached with a variety of geological and topographical conditions within a given basin results in a large spatial variability of flow regimes ranging from regimes partially fed by snowmelt in the rivers originating from Himalayan mountains, to regimes of alluvial plains rivers, which receive considerable base flow from groundwater in the autumn [15].

\subsection{Groundwater Potential and Land Legislation}

It would be worthwhile to discuss the importance of groundwater, the problems encountered in relation to ground water, constitutional position, the role of Central Groundwater Board (CGWB) \& Central Groundwater Activity (CGWA) and groundwater legislation in different states of India. Various problems that encountered in relation to ground water were over-escalation of ground water, depletion, emergence of water logging and salinity, equity in the context of the power driven extraction of groundwater through tube wells and bore wells and the problems of pollution and contamination of ground water. The vital problem in ground water management is equity and sustainability in the legal position that vest the ownership of water in the owner of land above it. Janakarajan et al. in their pioneering study on ground water from Tamil Nadu State argued that, there is increase in pollution, social inequality and conflict due to the over extrac- tion of ground water. There is no specific reference to the groundwater in Indian constitution though it is assumed that "water" includes groundwater. But with regard to easement rights as per the Indian Law, the ownership of land carries with it the ownership of the groundwater under its subject to regulation and control by the state. But it has been argued that this easement right makes the regulation difficult. There is no concerted nationwide effort to treat groundwater as a scarce and precious natural resource to be protected and conserved [16].

\subsection{Surface Water}

The relationship of the State with respect to irrigation in the Pre-British period was limited. There was dominance of military-civil engineering over the Irrigation development during British India [17]. Sengupta who advocates a renaissance of traditional irrigation technologies observed that, the irrigation technologies that developed during the British period had little understanding of the "irrigation science" [18]. Irrigation planning has been conceived of the high agenda of the builders of modern India. The allocation to irrigation and flood control through various five-year plans has continuously increased. The reason for huge investment in irrigation is the desire of the Indian planners to meet the food requirements of the ever-rising Indian population $[18,19]$. In the politics of cost \& benefit analysis, the irrigation planners can safely say that, there is need for large irrigation projects, in spite of the fact that the economic performance of large projects was hardly satisfactory. After the adoption of green revolution, the introduction of large-scale canal irrigation, particularly through the large dams has changed the ecology of the region. But, question arises that, whether construction of large dam can be self-sufficient to meet food production [19-21]. Paranjpye defines the economic value of water as the sums of the intrinsic value of water in nature that is the eco-system i.e. value of rivers, lakes, waterfalls, snow and ice on mountains, glaciers and polar caps, groundwater aquifers and soil \& air moisture [22]. By giving the example of the case of Maharashtra state, Paranjpye pointed out that, though the state experiences 40 per cent dams in India, only 10 per cent of the agricultural area is irrigated by the dams. On the other hand the state also facing acute drinking water problem, displacement and rigorous drought conditions [22].

Over the years the return from investment in irrigation has been constantly falling. The Planning Commission estimates that the cost involved in providing irrigation to one hectare of land through major \& medium irrigation schemes is over Rs. 2800 in comparison to Rs. 840 for an equal area by ground water. Apart from the cost of irrigation per ha, by major and minor schemes, any serious 
economic analysis must also look into the output per hectare by different irrigation technologies. One of the controversial issues is the debate of inter-relationship between large dams, trans-boundary water and conflicts. The main reason behind the construction of large dams in India were: for transferring water from the season of abundance to that of scarcity, for long distance water transfers from "surplus" areas to water short areas, for large scale hydropower generation, for flood moderation, for public water supply, and for navigation. The main contribution of the dam is also for the increased production of food grains. But, the main controversy of the large projects lies with its financial economic aspects, political economy aspects, environmental/ecological aspects and the aspects of displacement, rehabilitation \& resettlement. Some of these drafts cannot be remedied or even mitigated, and in some cases, efforts at the mitigation of or compensation for environmental impacts may in turn create further problem. Canal irrigation in India has been marked by a number of inequities in the headreach and tail end area. Since independence, not a single project in India had been completed within the approved cost estimates. Large dams are known to have a long gestation period, and in India are prone to frequent delays, even not a single project has been completed since independence within the stipulated target date.

Mani elucidates that, India is probably the first developing country which has integrated into its constitution precise requirements for environmental protection [23]. It has also been pointed out that, the central problem of legal framework for environmental protection in India is because of the abandon of 1986 Act. It is essential for studying the "Environmental impact Assessment" (EIA) of large projects. But, this EIA is having its own serious difficulties. It is being argued that, from a hydrological point of view, national or political boundaries should be ignored. A hydrological unit such as a basin or sub-basin should be taken as a whole and that there should be integrated water resource planning for such a visit. From an economic/political perspective, regional planning should be superior to national planning. There, a "bottom-up" approach should be followed rather than "top-down" approach. There is need for "stakeholder participation" for conflict resolution mechanism. Still the water conflict resolution with respect to the three treaties such as the Indus Treaty of September 1960 (India and Pakistan), the Mahakali Treaty of February 1996 (India and Nepal) and the Ganga Treaty of December 1996 (India and Bangladesh) are unresolved. India and Bangladesh argue that their lean season requirements are greater than the Ganges flow. Both the country agreed that "augmentation" is the solution, but true augmentation can only come from efficient use of water and tapping other sources of water.

\section{Land and Water Governance}

In many Indian states the administration and functional responsibilities for managing the land and water resources are unclear and spread over a number of different government institutions (viz. revenue departments, irrigation/water resources departments, public works department, groundwater boards, minor irrigation and tube well corporations, pollution control boards, municipal corporations etc.), making it particularly difficult to develop an integrated approach to land and water management. As with many countries, water administration is based on administrative boundaries rather than on hydrogeological boundaries, gives rise to several water sharing disputes among the states sharing a common river or other water resource ([6], emphasis added). The study by Palanisami et al., showed how the maximisation of revenue is possible by using irrigation tanks for various uses such as social forestry, brick making, fisheries, silt collection and groundwater recharge [24]. Roy explains that the surface water reservoirs such as tanks and ponds are the primary source of water for poor rural households for domestic uses, irrigation and fish production [25].

\subsection{Land Rights, Water Rights \& Laws and Privatization of Water}

The debate of water as a human right or human need and also the privatization of water is attracting for researchers. Justice Iyer's article on Nature's gifts: a case for safeguarding rivers, sand and other natural resources narrates that the State is a trustee of all the natural resources and is under a legal duty to defend it which could be intended for community use and could not be transformed into personal possession [26]. He also strongly argues that, selling or collaborating, removal of publicly owned water resources for mineral water rackets by manufacturing giants is unauthorized, unprincipled and violation of human rights. Singh in his paper on Reviving a dead river: story of the rejuvenation of the Ruparel river in Rajasthan describe a fascinating story how the NGO, Tarun Bharat Sangh, undertake a severe water paucity crisis in Rajasthan in a conventional way under the leadership of the "Water Man" Rajendra Singh by refreshing a dead river Ruparel which convey life reverse to the "dead land" in the huge area in Rajasthan [27]. On the whole it focuses on the positive impact of the Ruparel river basin which brings about a drastic change in the economy, ecology and lives of the people.

A number of significant questions have been raised about the land tenure rights and water rights. Water rights are concerned with the abstraction and use of water from natural sources. In India the responsibility for the operation and maintenance of state irrigation schemes has been transferred to the farmer operated water user 
associations (or Pani Panchayat) through the process of irrigation management transfer (IMT). As per the Orissa state Pani Panchayat Act, 2002, Section 4 (i), the beneficiaries of Pani Panchayats are only those who have lands. That means it is based on ownership of land and rights over land. This reveals that the poor and the landless people could not be given access to water, which is a common property resource. This makes obvious the impracticability of the provision in granting water rights to the landless. But rainfall belongs to the entire village community and all must have equal access to this water. The rights in land are rigid and inflexible and there is a basic inequity in the means of production and social structure. Hence, a natural right for irrigation water has become insecure and ineffective [28].

Siva's paper on privatization of water: a recipe for extinction of species and cultures argues that, privatization of water is the eventual human rights violations [29]. She has drawn attention some of the illustration of privatized river basin in India. She concluded that water is the belongings of the people, no MNC/private body or any other organization can appropriate it. Sharma depicted that, the World Bank is advocating for water as an economic good. By drawing experiences from many countries, Sharma argued that the privatization of water making the poor out of access to market. To get out from the water crisis, Sharma advocates for a modification of public sector and a community owned managed system of irrigation [30].

Barlow's article on Blue gold: who should control the world's water, has elucidated the debate of privatization and commoditization of water in the international spheres. It has been clear from her description that, there are ten major corporate players whose profit and employment increasing exponentially in distributing fresh water services [31]. All these private water companies were being paid financial assistances from the IMF and World Bank. Barlow explains that, for the World Bank and United Nations water is a human need instead of human right. While discussing the privatization of water, she also explains some of the role of the world water bodies such as Global Water Partnership, World Water Council (WWC), and World Commission on Water etc. Sustainable management of freshwater resources has accomplished significance at the regional and global scales [32-35]. Similarly "Integrated Water Resources Management” (IWRM) has also become the parallel precise paradigm. Access to safe freshwater is regarded as a universal human right, and the Millennium Development Goals include the extended access to safe drinking water and sanitation [34-36].

Some people consider water as a commodity, as commons, as a basic right and as a sacred resource or divinity. Iyer has argued that, water is now described as a more sophisticated formulation as economic and social good instead of water as a commodity. The notion of commons has also been using in the water sector but runs into difficulties in the context of private ownership, riparian rights etc. Some people were considering the idea of the individuals having rights to water as one perception. The water is in fact supports life and it is also a part of the natural environment sustaining it and also regarded as sacred. Some people were treating water as a "global commons". For instance the idea of a World Water contract has been proposed by Ricardo Petrella in the Water Minifesto as cited by Iyer [11].

Globally various principles and doctrines of riparian perspectives has been existed including the Harmone Doctrine of territorial sovereignty, the rights of "prior appropriation" or "prescriptive rights", the Helsinki principle of "equitable apportionment for beneficial uses" and the $1997 \mathrm{UN}$ convention on the non-navigational uses of international water courses. Many examples of Irrigation Act, rules regulation on formal law, Perspectives on water has been existed which are being judicial determinate in nature. All the different water rights, Act were having some significant limitations and were partial perspectives in nature. Do all the rights could assign centrality, could it arrange in a hierarchy, and would it be possible to integrate them into a harmonious whole?

\subsection{Inter-State Water Dispute}

This section will elucidate the relationship between water and the Indian Constitution, Inter-State Water Dispute Act 1956 (ISWD), national water policy and the idea of river basin planning. It is important to discuss the role of the Central Government, when water is not in the concurrent list. It is vital to analyze the appropriateness and adequacy of the different provisions related to water in the Constitution and the need for its amendments under changing climatic conditions. For example, the River Boards Act 1956 passed by the Parliament is only for the establishment of advisory boards, but the act is an inoperative one. Water is a state subject, but the role given by the constitution to the center in regard to interstate rivers is potentially an important one, which has not been used adequately. The process of decentralization and devolution in relation to water resource development are still evolving and the role of the third tier is yet to emerge fully. Iyer has identified many deficiencies of the present constitutional position in relation specific uses of water such as water supply, irrigation and canals, drainage and embankments, water storage and waterpower etc. that has been slipped from the entry 17 of the state list [11]. Again the constitution makers neglected the inclusion of ground water and intra-state surface waters. Further the constitutional provisions do not show any direct evidence of perception of water as a natural resource. There is also no evidence of the role of civil society and the awareness 
of traditional community-managed systems of rainwater harvesting. Iyer observed that, by shifting water to the concurrent list is just like enlarging the role of Central Ministry of Water Resources [11]. It is argued that, as water is a state subject, it is the states that are accountable for financing, cost recovery and management of surface irrigation and water supply associated activities within their territory. Even though the states have the most important duty for water sector financing, the center government also acting a noteworthy position by providing finances to states through central assistance, undertaking the construction of irrigation projects of national importance and implementing schemes such as the "Command Area Development" in canal regions [6]. Thus the debate about shifting water to the concurrent list merely is a question of power sharing among administrative structures. There can be a holistic view of water, better Centre-State and inter-state relations and consecutive relationship between State and Civil society relating to water [11].

There are many difficult experiences in the operation of the Inter-State Water Dispute Act 1956 in the case of the Krishna, Godavari, Cauvery, Narmada and Ravi-Beas. Though the Krishna, Godavari and Narmada Tribunals Awards have been inducing well, however Ravi-Beas case and the case of Cauvery dispute has been facing political difficulties. By analyzing procedural and fundamental criticisms, Iyer observed that, there is dissatisfaction with the constitutional and statutory provisions. The procedural criticisms existed in the nature of delaying at every stage of the various tribunals. On the other hand, the fundamental criticisms as described by Iyer were unsatisfactory dealing with water disputes, divisive adjudication, and lack of motivation by the judges and the absence of guidelines. Again there is problem of nonimplementation of the act. The ISWD Act says that the award is "final \& binding" and provides no appeal even to the Supreme Court. The National Commission to review the working of the constitution (NCRWC) has recommended the repeal of the ISWD Act and the enactment of a new Act. Its recommendation is to bring river water disputes within the original and exclusive jurisdiction of the Supreme Court. On the other hand Iyer, argues that the repeal of the ISWD Act would be singularly injudicious. Article 262 together with the ISWD Act represents a very good mechanism for dispute-regulation (as a last resort) when negotiations fail and it would be a great pity to dismantle it [11].

\subsection{India's National Water Policy}

Many countries have National Water Laws (NWL), but India is not having such law, instead of that there is a National Water Policy (NWP). The NWL will have to bring together all existing water-related laws under an overarching and unifying framework. The NWL would have to make clear distinctions between basic right to drinking water and other kinds of water rights. Again the NWL will also have to lay down a clear position of the role of the community or "civil society" and the relationship between the state and civil society with respect to water resources. The NWL should also provide a broad basis for the formation of registration of water users association (WUAs) and for such state wise legislation. The different rules regulations and Acts exists relating to irrigation, canals maintenance, generation of hydroelectric power, displacement, resettlement and rehabilitation of people. But, there is no separate set of laws rotating specifically to dam projects, but the planning, approval, financing construction operation and maintenance of such projects took place within the constitutional and legal framework of the country, and in particular, the provisions relating to water. For examples there are two important Acts, like the Environment Protection Act 1996 and the Forest Conservation Act 1980, which has a bearing on dam projects but is enacted by the central government. But as electricity is in the concurrent list and both the Center and the States can legislate, so the constitutional position is different for hydroelectric power. Similarly Land Acquisition Act is an important instrument of displacement.

The National Water Policy (NWP) 1987 was a slim document and its structure contents were vast covering the aspects of water as a scarce and precious national resource, human environment ecological etc. After the adoption of the NWP in September 1987, the Government of India constituted as an official-level body called the National Water Board (NWB) to consider the modalities of implementation of the NWP 1987. A new NWP (the revision of NWP 1987) was declared in 2002, which recognized the role of private sector participation and the need for a paradigm shift from resource development to efficient utilization of the developed resources. NWP 2002 was a wholly informal government exercise, with no consultations with people and institutions outside. Two most failures of the new NWP were in relation to water harvesting and community management of water. Important controversies such as those relating to water as "commodity" versus water as "commons" or a "basic right", the desirability of water markets etc were ignored in new NWP 2002. Presently, the Ministry of Water Resources is initiating the process of reviewing the National Water Policy of 2002, in order to have a final Draft National Water Policy (NWP, 2012).

\section{Land, Water, Climate and Environment Interface}

The most important environmental matter in the North has been coupled to changing climate, ozone reduction 
and contamination. It has been argued by them as, nature is rather outside economic assessment, somewhat to be detained in love, friendliness, wonder and horror [37]. For Kothari and Ahmad, the greatest communication gap in the world is the gap between the rich of the North and the poor of the South. They clearly identified that, the standard distinction among the three popular, radical and managerial environmental discourses lies in their categorization of the ecological crisis. They had also drawn attention on the Gandhian, Socialist and Marxist pressures of appraisal of development in the ecological crisis. This acquisitive observation of nature is required to be globalised by the wealthy North to complete its insensitive accompaniments. Thus the North's political colonisation of the South initially twisted into economic supremacy and then to eco-imperialism of nowadays. Kothari and Ahmad claim that man's endeavor to curve nature to his self-control is a result of western thought originating from the revitalization and afterward the writings of Thomas Hobbes and Rene Descartes. They strongly argue that, technology and market can assist a declaration of India's multiple ecological crises. The symbols of this fresh privilege are to be created in the support of market-based mechanism for environmental protection and in the laziness of the well-off towards the difficulty of project affected populations in their personal lands. The Natural environment vs. Development dispute in India is unmoving entrenched in common aggression [37].

In fact the climate change refers to any change in climate over time, whether due to natural variability or as a result of human activity. However, according to the UNFCCC, climate change refers to a change in climate that is attributed directly or indirectly to human activity that alters the composition of global atmosphere and which is in addition to natural climate variability observed over comparable time periods [38]. Focusing the global warming crisis due to climate change and its economic consequences presume vital importance in the process of realizing sustainable development, particularly in the developing economies [1]. Monty Schmitt reported that global warming would basically change rivers, streams and fish and wildlife will be harmed by changes to their habitat including increased temperature, degraded water quality and reduced water flow [1].

Souza's study on environmental discourses and environmental politics enlighten us that, in the Neo-Malthusian scheme ecological deprivation are the net outcome of population growth [39]. By drawing attention of some of the important ecological movements in India such as Chipko, Narmada Bachao Andolan, Tehri and Koel Karo, Chilika Bachao Andolan etc. Souza's argued that all these movements have a propensity to deliberate on issue base rationality rather than far-reaching political cohesiveness. He also argues that, the complete narration of ecological demolition is being modified traditionally as a creation of erroneous pricing, insufficient incentives, free riders, subsidies, ineffectiveness and indistinctness in property rights. Further Souza makes sure that there is no peculiarity between the professed capitalists and socialists when it approaches to ruin environment. While describing some of the important case of privatization of water sector he believes that there would be distorted and disproportionate society that exaggerates the difficulty of destitute in India. Nevertheless, the environmental harm caused in the earlier socialist component of the world was no fewer than what capitalism fashioned in a different place. India, which accepted socialism subsequent to Independence, has currently turned into a votary of the open market and market conservationism. Uphill struggle of NGOs to move backward this tendency are handicapped by their diverse class structure with dissimilar classes perceiving and act in response to problems in a different way. The complexity in understanding the said observation is that they set down small opportunity for coherent preference so much involved in the actual humankind. Souza sought to discover and recognize the source for a Red and Green dialogue in India [39].

Climate change affects agriculture, coastal regions, economic goods and services, health sector, eco-systems and opportunity through extreme events. These affected sectors are the important sector for the sustainability of livelihood in the developing countries and also highly sensitive to climate change. Moreover, a larger percentage of the population in the developing countries has lower standard of living i.e. below poverty line (More than 700 million people are below $\$ 1$ per day), and they are more dependent on natural resources for their livelihood, which are highly sensitive to climate change. Developing countries are already under stress from different backgrounds, but climate change will bring additional burden or cost to them and put them again in the vicious circle of poverty. Every day many people die due to hunger in developing nations while climate change brings additional burden through reducing their purchasing power and shortage of food production. Poverty has radically widened in many countries in the last two decades of the 20th century, making poverty reduction the core challenge for the development in the 21st century. However, climate change is a serious threat to poverty reduction and development effort. This being the case, there is a need to analyse the impact of global warming problems at the regional and local levels so that one could develop strategies to reduce the vulnerability of the poorer people who will be the most affected.

\section{Conclusions}

Economic theory advocated that, the global warming crisis is the outcome of the problem of "tragedy of the 
commons" occurring from the selfish behavior of the countries. Each living being has the right to enjoy and destroy it but in fact it examines an inequity in the distribution of common property. Since the services provided by the atmosphere possess the characteristics of "public goods", each country has the incentive to pass the responsibility of preserving the atmosphere to other countries. It has also important property as non-exclusion that one nation's consumption can't affect the consumption of other nations. Climate change also affects the countries' sustainable development path and hampers the needs and brings an additional costs, burden and stress to the future generations.

The detailed documentation required to improve understanding and estimation, in quantitative terms, of climate change impacts on freshwater resources and their management, to fulfill the pragmatic information needs of water managers who are responsible for adaptation. Relatively few results are available on the economic aspects of climate change impacts and adaptation options related to water resources, which are of great practical importance. Research into human-dimension indicators of climate change impacts on freshwater is in its infancy and vigorous expansion is necessary. There are challenges and opportunities posed by the advent of probabilistic climate change scenarios for water resources management. Despite its significance, groundwater has received little attention from climate change impact assessments, compared to surface water resources. Data on water use, water quality, and sediment transport are even less readily available [6].

There are well-developed scientific researches on climate change, whereas the research on economics of climate change has some lag. In the last two decades, there is research going on national, global level but there is a lag in local level research on the impacts, vulnerability and adaptation of climate change. In a changing environment the problem of siltation, soil salinity, biodiversity, food insecurity, the problems of watershed disputes, competing and conflicting demand for natural resources across sectors, agrarian relations, environmental problem, ground water depletion etc have surfaced as a major issue. Hence, unless one approaches these issues in the context of variability, changes and openness, it would be extremely difficult to realise the techniques of sustainable management of natural resources on a watershed scale, managed by the local community for food security, environmental quality and livelihood opportunities.

\section{Acknowledgements}

The authors are thankful to their respective employer for providing necessary facilities and conducive academic environment to come up with this manuscript. Authors are also thankful to the anonymous reviewers for their valuable comments.

\section{REFERENCES}

[1] Natural Resource Defense Council, “Annual Report 2007,” Natural Resource Defense Council, Sanfranisco, 2007.

[2] World Bank, "Climate Change Impacts in Drought and Flood Affected Areas: Case Studies in India,” Social, Environment and Water Resources Management Unit, India Country Management Unit (South Asia Region), New Delhi, Report No. 43946-IN, 2008.

http://www.worldbank.org.in

[3] F. Soltau, "Climate Change and Sustainable Development: Understanding the Linkages," Natural Resources Forum, Vol. 30, No. 4, 2006, pp. 253-255. doi:10.1111/j.1477-8947.2006.00125.x

[4] J. Disano, "Climate Change and Sustainable Development," Natural Resources Forum, Vol. 30, No. 4, 2006, pp. 251252. doi:10.1111/j.1477-8947.2006.00123.x

[5] G. H. Brundtland, "Development and International Economic Co Operation: Environment,” Report of the World Commission on Environment and Development, Tokyo. 1987.

[6] B. R. Sharma and P. G. McCornick, "India Country Case Study on Domestic Policy Frameworks for Adaptation in the Water Sector, Working Together to Respond to Climate Change. Annex I Expert Group Seminar in Conjunction with the OECD Global Forum on Sustainable Development,” International Water Management Institute, New Delhi, 2006.

[7] U. A. Amarasinghe, B. R. Sharma, N. Aloysius, C. Scott, V. Smakhtin, C. de Fraiture, A. K. Sinha and A. K. Shukla, "Spatial Variation in Water Supply and Demand across River Basins of India. IWMI Research Report 83,” International Water Management Institute, Colombo, 2005.

[8] A. Vaidyanathan, "Interlinking of Rivers I," The Hindu, 26 March 2003.

[9] A. Vaidyanathan, "Interlinking of Rivers II," The Hindu, 27 March 2003.

[10] A. Vaidyanathan, "Interlinking of Peninsular Rivers-A Critique," Economic and Political Weekly, Vol. 38, No. 27, 2003, pp. 2865-2872.

[11] R. R. Iyer, "Water Perspectives, Issues, Concerns,” Sage Publications of India Pvt. Ltd., New Delhi, 2003.

[12] M. Q. Mirza and N. J. Erickson, "Impact of Water Control Projects on Fisheries Resources in Bangladesh,” Environmental Management, Vol. 20, No. 4, 1996, pp. 527 539. doi:10.1007/BF01474653

[13] B. R. Sharma and V. U. Smakhtin, "Water Harvesting as a Strategic Tool for Drought Mitigation in Southwest Asia," Proceedings of 55th International Meeting of the International Commission on Irrigation and Drainage, FAO/ICID International Workshop on Water Harvesting and Sustainable Agriculture, Moscow, 6-10 September 2004.

[14] P. J. Webster, V. O. Magana, T. N. Palmer, J. Shukla, R. A. Thomas, M. Yanagi and T. Yasunari, "Monsoons: Processes, Predictability and the Prospects of Prediction," 
Journal of Geophysical Research, Vol. 103, No. 7, 1998, pp. 14451-14510. doi:10.1029/97JC02719

[15] J. Bandyopadhaya, "Water Management in the GangesBrahmaputra Basin: Emerging Challenges for the 21st Century," Water Resources Development, Vol. 11, No. 4, 1995, pp. 411-442.

[16] S. Janakarajan and M. Moench, "Wells and Ill Fare: Conditions and Characteristics of Groundwater Irrigation in Tamil Nadu,” Water Nepal, Vol. 12, No. 1-2, 2006, pp. 47-80.

[17] S. Singh, "Taming the Waters, The Political Economy of Large Dams in India,” Oxford University Press, Oxford, 2002.

[18] N. Sengupta, "Irrigation: Traditional vs Modern,” Economic and Political Weekly, Special No. on Natural Resource Utilisation, November 1985.

[19] N. Sengupta, "Managing Common Property, Irrigation in India and the Philippines," Sage Publications India Pvt. Ltd., New Delhi, 1991.

[20] N. Sengupta, “User Friendly Irrigation Designs," Sage Publications India Pvt. Ltd., New Delhi, 1993.

[21] N. Sengupta, “Technology, Management and Control the Indigenous System of Irrigation in South Bihar,” In: R. Guha Ed., Social Ecology, Oxford University Press, Oxford, 2001.

[22] V. Paranjpye, "The Value and Politics of Water in India," In: S. Kothari, I. Ahmad and H. Reifeld, Eds., The Value of Nature-Ecological Politics in India, Konrad Adenauer Stiftung, Rainbow Publishers Ltd., New Delhi, 2003.

[23] V. S. Mani, "Environmental Law in South Asia: An Overview,” In: S. Kothari, I. Ahmad and H. Reifeld, Eds., The Value of Nature-Ecological Politics in India, Konrad Adenauer Stiftung, Rainbow Publishers Ltd., New Delhi, 2003.

[24] K. Palanisami, R. Meinzen-Dick and M. Giordano, "Climate Change and Water Supplies: Options for Sustaining Tank Irrigation Potential in India,” Economic and Political Weekly, Vol. 26-27, 2010, pp. 183-190.

[25] M. Roy, "Managing the Village-Level Open-Access Water Resources in a Region Facing Rapidly Declining Water Availability," Environment, Development and Sustainability, Vol. 12, No. 6, 2010, pp. 999-1012. doi:10.1007/s10668-010-9237-9

[26] V. R. K. Iyer, "Nature’s Gifts: A Case for Safeguarding Rivers, Sand and Other Natural Resources,” In: S. Yadav, Ed., Water Problem and Its Management, Hope India Publications, Haryana, 2004.

[27] V. Singh, "Reviving a Dead River: Story of the Rejuvenation of the Ruparel River in Rajasthan,” In: S. Yadav, Ed., Water Problem and Its Management, Hope India Publications, Haryana, 2004.
[28] S. K. Mahapatra, "Functioning of Water Users Associations or Pani Panchayat in Orissa: Principle, Procedure, Performance and Prospects," Law, Environment and Development Journal, Vol. 3, No. 2, 2007, p. 126.

[29] V. Siva, "Privatisation of Water: A Recipe for Extinction of Species and Cultures," In: S. Yadav, Ed., Water Problem and Its Management, Hope India Publications, Haryana, 2004.

[30] S. Sharma, "Water Markets Exclude the Poor," In: S. Kothari, I. Ahmad and H. Reifeld, Eds., The Value of Nature-Ecological Politics in India, Konrad Adenauer Stiftung, Rainbow Publishers Ltd., New Delhi, 2003.

[31] M. Barlow, "Blue Gold: Who Should Control the World's Water?” In: S. Yadav, Ed., Water Problem and Its Management, Hope India Publications, Haryana, 2004.

[32] United Nations, "Johannesburg Plan of Implementation of the World Summit on Sustainable Development," United Nations, New York, 2002, p. 72.

[33] United Nations, "World Water Development Report: Water for Life, Water for People,” UNESCO, Paris, and Berghahn Books, Barcelona, Spain, 2003, p. 544.

[34] United Nations Committee on Economic Social and Cultural Rights, "General Comment No. 15 on the Right to Water E/C.12/2002/11,” United Nations Social and Economic Council, New York, 2003, p. 18.

[35] United Nations, "World Water Development Report 2: Water: A Shared Responsibility,” UNESCO, Paris, 2006, p. 601.

[36] Z. W. Kundzewicz, L. J. Mata, N. W. Arnell, P. Döll, P. Kabat, B. Jiménez, K. A. Miller, T. Oki, Z. Sen and I. A. Shiklomanov, "Freshwater Resources and Their Management, Climate Change Impacts, Adaptation and Vulnerability, Contribution of Working Group II to the Fourth Assessment Report of the Intergovernmental Panel on Climate Change,” In: M. L. Parry, O. F. Canziani, J. P. Palutikof, P. J. van der Linden and C. E Hanson, Eds., Cambridge University Press, Cambridge, 2007, pp. 173210.

[37] S. Kothari, I. Ahmad and H. Reifeld, Eds., "The Value of Nature-Ecological Politics in India,” Konrad Adenauer Stiftung, Rainbow Publishers Ltd., New Delhi, 2003.

[38] Intergovernmental Panel on Climate Change (IPCC), “Climate Change 2001: Impacts, Adaptations and Vulnerability, Summary for Policy Makers,” World Meteorological Organization, Geneva, 2001.

[39] R. D. Souza, "Environmental Discourses and Environmental Politics,” In: S. Kothari, I. Ahmad and H. Reifeld Eds., The Value of Nature-Ecological Politics in India, Konrad Adenauer Stiftung, Rainbow Publishers Ltd., New Delhi, 2003. 